\title{
Analisis Fraksi Volume Serat Pelepah Batang Pisang Bermatriks Unsaturated Resin Polyester (UPR) Terhadap Kekuatan Tarik dan SEM
}

\author{
Tumpal Ojahan R. ${ }^{1}$, Hansen Aditia M.S. ${ }^{2}$ \\ ${ }^{1,2}$ Program Studi Teknik Mesin, Fakultas Teknik Universitas Malahayati \\ Jl. Pramuka No. 27 Kemiling, Bandar Lampung, Email : tumpal_ojahan@yahoo.com
}

\begin{abstract}
Abstrak
Serat alam telah terbukti sebagai material yang kuat, mampu untuk menggantikan serat sintetik sebagai penguat. Serat batang pisang kepok salah satu serat yang memiliki potensi sebagai penguat untuk polyester material komposit. Pada material komposit berpenguat(fiber) serat batang pisang kepok dapat menahan beban yang diterima material komposit. Sedangkan unsaturated resin polyester $(U P R)$ sebagai pengikat serat batang pisang, bekerja menahan beban dan melindungi serat dari kerusakan. Hasil pengujian kekuatan tarik yang paling optimal terdapat pada volume fraksi $28 \%$ fiber : $72 \%$ matriks dengan gaya maksimum 2327,9 $\mathrm{N}$, tegangan tarik 67,2065 N/mm ${ }^{2}$, regangan 2,7477\% serta modulus elastisitas $3441,82 \mathrm{~N} / \mathrm{mm}^{2}$. Pada pengamatan SEM fraksi volume $28 \%$ filler : $72 \%$ matriks paling optimal karena adanya ikatan matriks dan serat menyatu dengan sempurna. Dari penelitian ini dapat disimpulkan bahwa pengaruh fraksi volume serat batang pisang kepok sebagai penguat (fiber) dan unsaturated resin polyester (UPR) sebagai pengikat (matriks) pada material komposit akan mempengaruhi kekuatan material kompositlebih kuat dan ulet.
\end{abstract}

Kata kunci : serat pisang kepok, komposit, fraksi volume, kekuatan tarik, SEM

\section{PENDAHULUAN}

Polimer merupakan bahan yang sangat bermanfaat dalam dunia teknik, khususnya dalam industri kontruksi. Polimer sebagai bahan kontruksi bangunan dapat digunakan baik berdiri sendiri, misalnya sebagai perekat, pelapis, cat, dan sebagai glazur maupun bergabung dengan bahan lain membentuk komposit. Untuk aplikasi struktur yang memerlukan kekuatan dan ketegaran,diperlukan perbaikan sifat mekanik polimer agar memenuhisyarat. Untuk kebutuhan tersebut, berkembanglah komposit polimer yang disertai penguat oleh berbagaifiller di antaranya serat [1].

Bahan polimer yang biasa digunakan dalampembuatan komposit adalah polimer jenis termoset.Pemilihan bahan ini didasarkan bahwa polimer termosetmemiliki ketahanan terhadap suhu dan bahan kimia ataupelarut yang disebabkan wujudnya yang cair dankekentalannya tidak terlalu tinggi sehingga mampu membasahi permukaan serat Epoksi dan polyester merupakan polimer termoset yang biasa digunakan dalampembuatan komposit polimer [2].
Sifat bahan komposit sangat dipengaruhi oleh sifatdan distribusi unsur penyusun, serta interaksi antara keduanya [2]. Parameter penting lain yang mungkin mempengaruhi sifat bahan komposit adalah bentuk,ukuran, orientasi dan disribusi dari penguat (filler) dan berbagai ciri-ciri darimatriks [3]. Sifat mekanik merupakan salah satu sifat bahan komposit yang sangat penting untuk dipelajari. Untuk aplikasi struktur, sifat mekanikditentukan oleh pemilihan bahan [4]. Sifat mekanik bahan komposit bergantung pada sifat bahan penyusunnya.Peran utama dalam komposit berpenguat serat adalahuntuk memindahkan tegangan (stress) antara serat, memberikan ketahanan terhadap lingkungan yang merugikan dan menjaga permukaan serat dari efek mekanik dan kimia. Sementara kontribusi serat sebagian besar berpengaruh pada kekuatan tarik (tensile strength) bahankomposit [5].

Menurut Tumpal Ojahan [6], Semakin tinggi volume fraksi maka tegangan tarik dan kekuatan tarik material komposit semakin meningkat dan Semakin besar volume fraksi serat batang pisang sebagai penguat (fiber) dan recycled polypropylene (RPP) sebagai pengikat (matriks) maka semakin tinggi tegangan, 
regangan, kekuatan dan ketangguhan. Hal ini dikarenakan kekuatan ikatan matriks dengan serat meningkat, kekuatan tarik tertinggi terdapat pada pada volumefraksi $\mathrm{Fl} 35 \%$ : Mt $65 \% \sigma_{\mathrm{t}}=8,508 \mathrm{MPa}$.Analisa kekuatan tarik komposit thermoplastik diperkuat serat daun nanas, pembuatan komposit dilakukan secara hand lay up, bahan yang digunakan adalah resin polyester dan variasi fraksi volume adalah $20 \%, 30 \%$ dan $35 \%$. Hasil pengujian menunjukan kekuatan tarik terbesar rata-rata terdapat pada fraksi volume 35\% [7]. Junior [8], melakukan penelitian tentang sifat mekanis komposit serat kelapa dengan resin poliester. Setelah dilakukan pengujian dan foto SEM didapatkan fraksi volume serat yang optimal dari komposit serat kelapa yang dapat menahan perambatan retak.

Menurut Lokantara [9], meneliti tentang pengaruh panjang serat dan temperatur udara terhadap kekuatan tarik komposit polyester tapis kelapa dengan variasi panjang serat tapis kelapa yaitu $5 \mathrm{~mm}, 10 \mathrm{~mm}$ dan $15 \mathrm{~mm}$ sedangkan variasi temperatur udara yaitu $-5^{\circ} \mathrm{C}$, $10^{\circ} \mathrm{C}$ dan $25^{\circ} \mathrm{C}$. Komposit yang dibuat menggunakan penguat serat tapis kelapa dengan matrik berupa resin unsaturated polyester, hasil pengujian menunjukan variasi panjang serat dan temperatur udara mempengaruhi kekuatan tarik pada komposit .Kartini [10], Nilai kekuatan tarik serat ijuk lebih tinggidaripada serat pisang disebabkan bentuk geometri seratpisang berbeda dengan serat ijuk. Bentuk geometri seratpisang berupa lembaran, sedangkan serat ijuk berupasilinder panjang dengan perbandingan antara panjangdengan diameternya sangat besar. Dengan semakinbanyak serat ijuk pada matriks polimer, maka luaspermukaan bidang batas antarmukanya semakin besaryang membuat bahan komposit lebih kuat.Menurut Tumpal [11]. Analisa kekuatan pukul takik dan SEM dengan variasi fraksi volume komposit bermatriks RPP terhadap filler serat batang pisang, dapat meningkatkan kekuatan akibat filler.

Penelitian ini akan dibuat komposit polimer yang diperkuat serat alam berupa serat pelepah pisang kepok dan menggunakan matriks resin polyester, setelah itu akan dilihat pengaruh penambahan serat ke dalammatriks polimer terhadap kekuatan tarik sertamengetahui struktur ikatan antara komponen matriks dan pengisi komposit serat batang pisang dengan hasil pengamatan photo SEM (Scanning Electron Microscope).

\section{BAHAN DAN METODA}

Bahan matriks yang digunakan dalam penelitian ini adalahresin polyestermerek Yukalak 157 BQTN-EX, pengerasnya adalah hardener versamid 140, pengeringnya digunakan katalis MEKPO (metil etil keton peroksida), serat pisang kepok yangdiambil dari pohon pisang kepok (Musa paradisiacal L.) di daerahBandar Lampung, sertawax mold sebagai bahan untuk memudahkan melepaskan sampel dari cetakan.Alat yang digunakan dalam penelitian ini adalah:

1. Alat cetakan yang terbuat dari kaca dengan ketebalan $4 \mathrm{~mm}$ dan dututup mengunakan kaca pada bagian atas dan bagian bawah cetakan.

2. Mesinpress dingin (hydraulic press)

3. Timbangan digital dan alat ukurmicrometer.

4. Mesin uji tarik, mesin uji bending, mesin uji impact dan alat Scanning Electrone Microscope (SEM)

5. Alat bantu lainnya yaitu sarung tangan, pisau,gelas ukur, timbangan, amplas, spidol dan kuas.

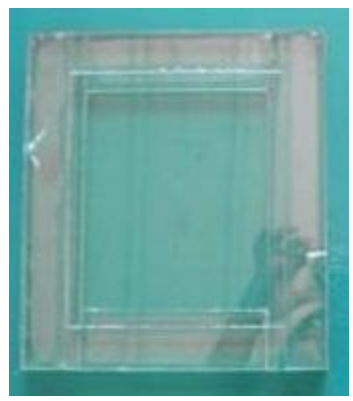

Gambar 1. Cetakan Komposit (Juni 2014)

\section{METODA PENELITIAN}

\section{a. Pembuatan sampel}

Pertama permukaan bagian dalam dari alat cetak diolesi dengan wax secukupnya. Resin polyester dicampur dengan katalis dengan perbandingan berat 100:1 dan diaduk sampai rata selama 2menit. Resin dan katalis dituangkan pada cetakan setengah bagian, lalu ditambahkan serat dengan susunan serat sejajar (continuous), berikutnya tuangkan kembali resin dan katalis yang tersisa setengah bagian, lalu ditutup dengan cetakan kaca. Selanjutnya 
cetakan diberi tekanan $20 \mathrm{~kg} / \mathrm{cm}^{2}$ sampai material komposit kering.

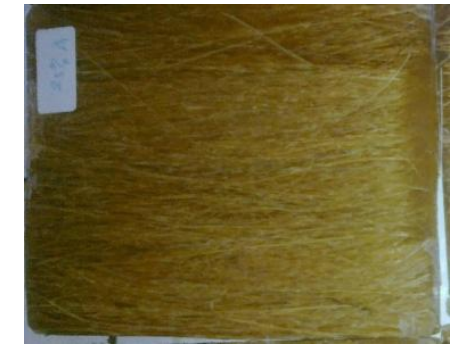

Gambar 2. Komposit Serat Pisang

\section{b. Bentuk Sampel}

Bentuk material komposit setelah kering berbentuk persegi, kemudian dilakukan reparasi spesimen seperti pada Gambar 3

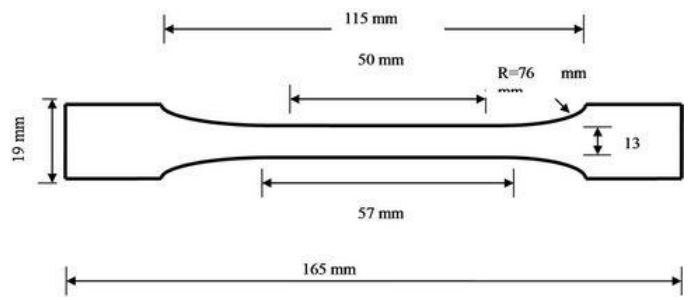

Gambar 3. Bentuk sampel uji tarik dengan strandar

ASTM D638-4

\section{c. Karakterisasi}

Karakterisasi ini dilakukan pada sampel yang telah dibuat meliputi :

1. Uji tarik, dari uji ini diperoleh informasi kekuatan tarik (tensile strength), regangan, beban maksimum dan modulus elastisitas.

2. Foto SEM, dari uji ini diperoleh informasi jenis patahan yang terjadi pada vf $28 \%$ : $72 \%$.

\section{HASIL UJI TARIK}

Data hasil uji tarik ditunjukkan padaTabel 1, tetapi berdasarkan data yang diperoleh tidak ada nilai untuk perpanjangan patah (elongation at break).
Tabel 1. Hasil Uji Tarik Komposit

\begin{tabular}{ccccc}
\hline \multicolumn{5}{c}{ Tabel Hasil Uji Tarik } \\
\hline \multicolumn{5}{c}{ Pengujian } \\
\hline $\begin{array}{c}\text { Fraksi } \\
\text { Volume }\end{array}$ & $\begin{array}{c}\text { Tegangan Regangan } \\
\text { Tarik } \\
\left(\mathbf{N} / \mathbf{m m}^{2}\right)\end{array}$ & $\begin{array}{c}\text { Tarik } \\
(\boldsymbol{\%})\end{array}$ & $\begin{array}{c}\text { Beban } \\
\text { Maksimum } \\
(\mathbf{N})\end{array}$ & $\begin{array}{c}\text { Modustisitas } \\
\left(\mathbf{N} / \mathbf{m m}^{2}\right)\end{array}$ \\
\hline $10 \%$ & 38.6666 & 1.91927 & 1109.25 & 3437.74 \\
$16 \%$ & 46.4499 & 2.02149 & 1389.86 & 3327.94 \\
$22 \%$ & 58.7461 & 2.51438 & 1843.00 & 3167.37 \\
$28 \%$ & 67.2065 & 2.74774 & 2327.93 & 3441.82 \\
$34 \%$ & 64.3162 & 2.75099 & 2381.88 & 3435.79 \\
\hline
\end{tabular}

Setelah dilakukan pengujian tarik komposit bermatriks Resin Polyester berpenguat serat batang pisang kapok dengan arah serat sejajar dengan tegangan tarik, rengangan tarik dan modulus elastisitas cenderung mengalami peningkatan.

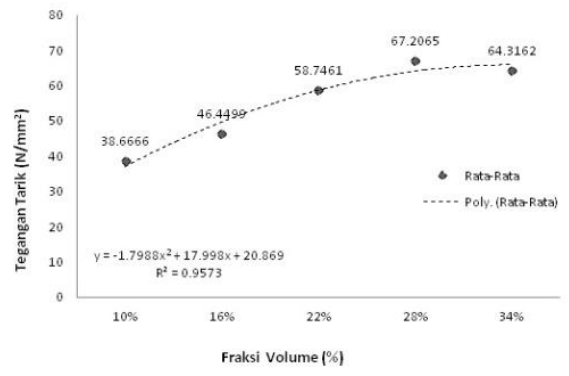

Gambar 2. Kurva Tegangan Tarik

Kurva tegangan tarik - volume fraksi cenderung mengalami peningkatan, adapun tegangan tarik tertinggi berada pada vf $28 \%$ fiber dengan rata-rata $67.2065 \mathrm{~N} / \mathrm{mm}^{2}$ dan ratarata terendah terdapat pada of $10 \%$ fiber yaitu $38.6666 \mathrm{~N} / \mathrm{mm}^{2}$.

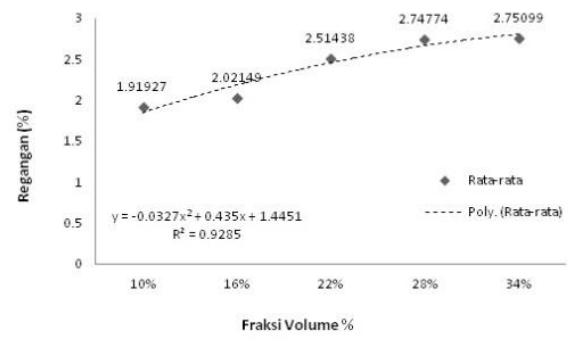

Gambar 3. Kurva ReganganTarik

Kurva regangan-volume fraksi material komposit mengalami peningkatan, regangan rata-rata tertinggi terdapat pada vf $34 \%$ fiber sebesar $2.75099 \%$ dan rata-rata terendah terdapat pada vf $10 \%$ fiber yaitu $1.91927 \%$. Peningkatan regangan dipengaruhi penambahan 
volume fraksi, serta disebabkan adanya peningkatan daya ikat antara martiks dengan fiber.

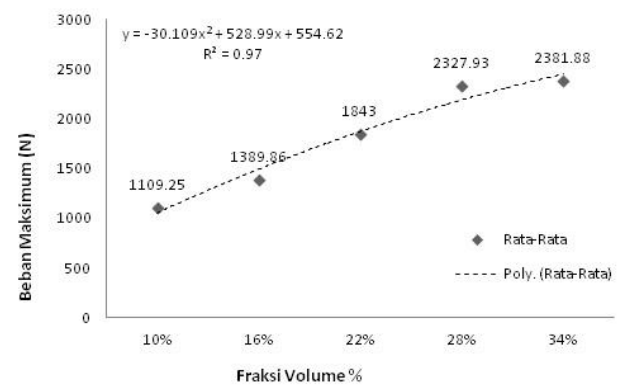

Gambar 4. Kurva Beban maksimum Uji Tarik

Kurva beban maksimum - volume fraksi material komposit mengalami peningkatan, regangan rata-rata tertinggi terdapat pada vf $34 \%$ fibersebesar 2381.88 Ndan rata-rata terendah terdapat pada vf $10 \%$ fiber yaitu 1109.25 N.Peningkatan nilai beban maksimum dipengaruhi penambahan volume fraksi, serta disebabkan adanya peningkatan daya ikat antara martiks dengan fiber.

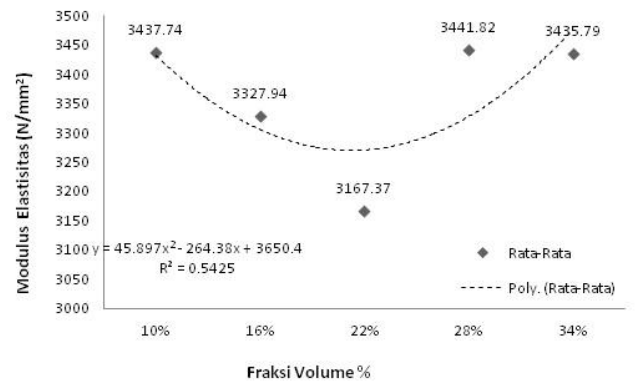

Gambar 5. Kurva Modulus Elastisitas Uji Tarik

Kurva modulus elastisitas serat - volume fraksi yang tertinggi berada pada vf10\% fiber yaitu $3437.74 \mathrm{~N} / \mathrm{mm}^{2}$, sedangkan modulus elastisitas terendah terdapat pada fraksi volume $22 \%$ fiber yaitu $3167.37 \mathrm{~N} / \mathrm{mm}^{2}$.

\section{PEMBAHASAN}

Secara garis besar volume fraksi sangat berpengaruh terhadap kekuatan tarik hal ini disebabkan karena penguat serat sudah semakin bertambah dan pengikat berkurang, sementara dimensi dari material tidak mengalami perubahan. Dari tabel hasil uji tarik komposit mengalami peningkatan mulai dari fraksi volume $10 \%$ sampai $28 \%$ fiber, hal ini serat berfungsi sebagai penguat (fiber) mempunyai sifat tarik yang kuat dibandingkan dengan pengikatnya (matriks)Resin Polyester. Apabila dari hasil pengujian terdapat kekuatan tarik menurun ini disebabkan penyusunan serat atau konsentrasi serat pada matriks tidak tersusun dengan baik dan bisa juga disebabkan oleh kadar air dari serat, serta adanya lignin terdapat diserat sehingga dapat menurunkan sifat kekuatan serat. Pada saat proses pencetakan dan pengepresan juga dapat mempengaruhi kekuatan tarik material komposit karna dapat menyebabkan rongga udara (Void).

\section{Pengamatan SEM Komposit.}

Photo SEM dilakukan untuk mengetahui struktur ikatan antara serat sebagai penguat (fiber) dengan Resin Polyester sebagai pengikat (matriks)

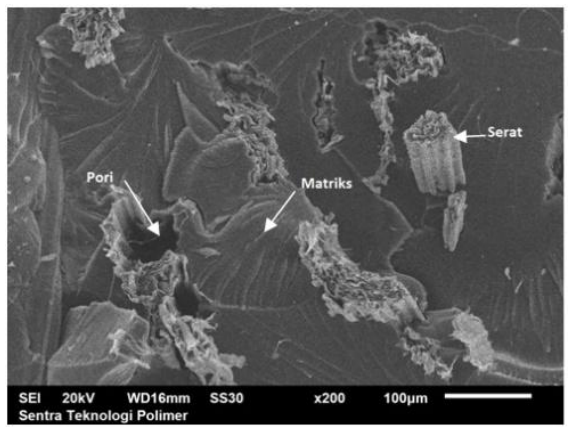

Gambar 6. Pengamatan SEM Komposit fl 10\%: $m t 90 \%$

Menunjukan hasil uji SEM komposit serat batang pisang sebelum dilakukan uji tarik dengan pengikat Resin Polyester dari hasil uji SEM tampak dengan jelas matriks dan serat merekat dengan baik dikarenakan belum tampak kerusakan yang terjadi tetapi sudah terbentuk pori, hal ini diakibatkan fiber dan matriks belum mengikat dengan sempurna. 


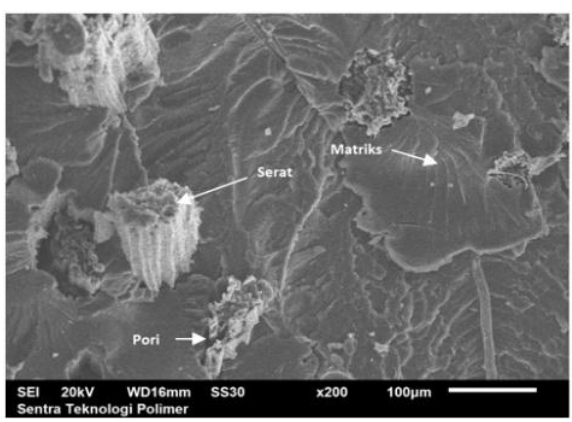

Gambar 7. Pengamatan SEM Komposit fl $16 \%: m t 84 \%$

Hasil uji SEM komposit serat batang pisang sejajar serat setelah dilakukan uji tarik dengan pengikat Resin Polyester dari hasil uji SEM tampak dengan jelas matriks dan serat merekat dengan baik dapat dilihat setelah kerusakan permukaan komposit setelah uji tarik, masih sedikit terlihat adanya serat yang tercabut, menimbulkan pori.

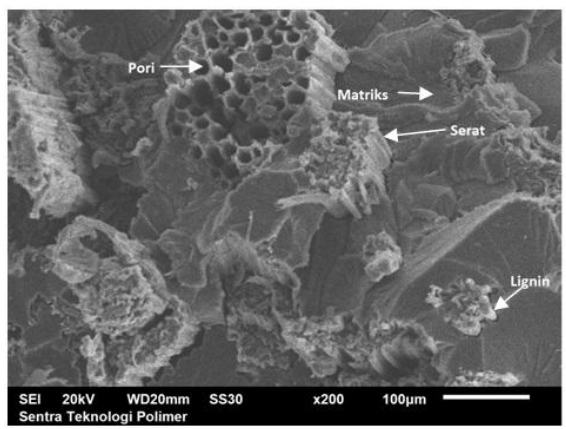

Gambar 8. Pengamatan SEM Komposit fl $22 \%: m t 78 \%$

Menunjukkan hasil uji SEM komposit serat batang pisang sejajar serat setelah dilakukan uji tarik dengan pengikat Resin Polyester dari hasil uji SEM tampak dengan jelas matriks dan serat merekat dengan baik dapat dilihat setelah kerusakan permukaan komposit setelah uji tarik, terlihat adanya serat yang tercabut lebih banyak dan menimbulkan pori.

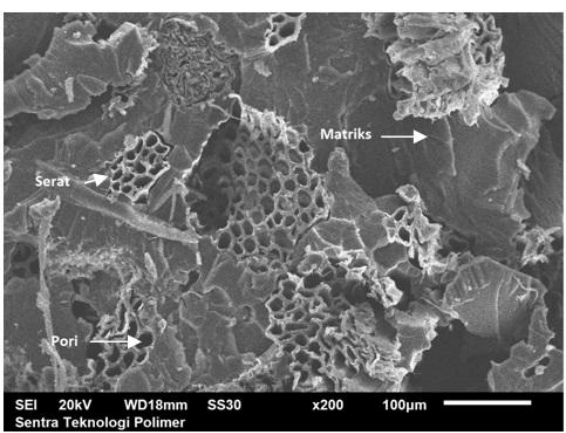

Gambar 9. Pengamatan SEM Komposit fl 28\%: $m t 72 \%$

Hasil uji SEM komposit serat batang pisang sejajar serat setelah dilakukan uji tarik dengan pengikat Resin Polyester hasil tampak dengan jelas matriks dan serat merekat dengan baik dapat dilihat setelah kerusakan permukaan komposit setelah uji tarik, terlihat serat yang tercabut lebih banyak dan menimbulkan pori.

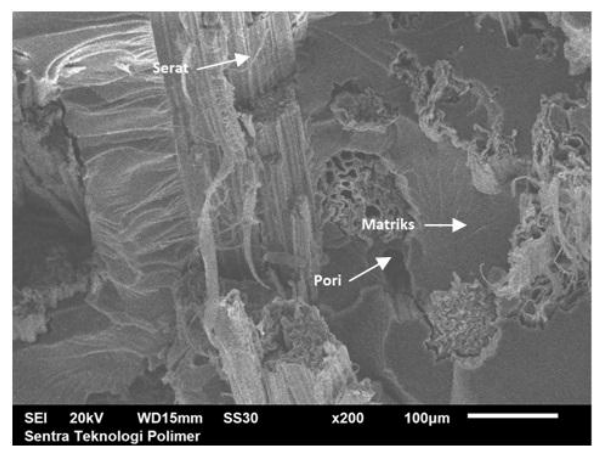

Gambar 10. Pengamatan SEM Komposit fl 34\% : $m t 66 \%$

Menunjukan hasil uji SEM komposit serat batang pisang sejajar serat setelah dilakukan uji tarik dengan pengikat Resin Polyester dari hasil uji SEM tampak dengan jelas matriks dan serat merekat dengan baik dapat dilihat setelah kerusakan permukaan komposit setelah uji tarik, masih sedikit terlihat adanya serat yang tercabut dan menimbulkan pori adapun tegangan tarik rata-rata tertinggi pada fraksi volume $F l 34 \%:$ Mt $66 \% \sigma_{\mathrm{t}}=64.3162 \mathrm{~N} / \mathrm{mm}^{2}$.

\section{KESIMPULAN}

1. Semakin tinggi volume fraksi maka tegangan tarik dan kekuatan tarik material komposit semakin meningkat.

2. Semakin besar volume fraksi serat batang pisang sebagai penguat (fiber) dan 
Unsaturated Resin Polyester (UPR) sebagai pengikat (matriks) maka semakin tinggi tegangan, regangan, kekuatan dan ketangguhan, hal ini dikarenakan kekuatan ikatan matriks dengan serat meningkat.

3. Kekuatan tarik maksimum komposit resin polyester dengan penguat serat batang pisang terdapat pada fraksi volume $28 \%$ jika lebih dari $28 \%$ kekuatan komposit akan mengalami penurunan kekuatan tarik.

\section{DAFTAR PUSTAKA}

[1]. Feldman, Dorel and Anton J. H. BahanPolimer Kontruksi Bangunan. Gramedia PustakaUtama. Jakarta.(1995).

[2]. Bhagwan D, Agarwal. Analysis andPerformance of Fiber Composite. John Wiley \&Sons.NewYork.(1980)

[3]. Mathew, F. L, And R.D.Rawlings. Composite Materials: Engineering and Science. Chapman\&Hall. London. (1994)

[4]. Colling, Davida., and Thomasvasilos. IndustrialMaterial: Polyme Ceramics andComposite. Vol 2. PrenticeHall. (1995)

[5]. Nicolais, L., et. al. Sciense and Technology ofPolymer Composite. Di dalam Güneri Akovali(editor). The Interfacial Interaction in PolimerComposites.NatoasiSeries.Nether lands.(1993)

[6]. Tumpal Ojahan R.,Analisa Kekuatan Pukul Takik Dan SEM Dengan Variasi Fraksi Volume Komposit Bermatriks RPP Terhadap Filler Serat Batang Pisang,Proseding BKS-TM XII Unila, Oktober 2013

[7]. Zhohanes, 2010, "Pengaruh Fraksi Volume Terhadap Kekuatan Tarik Komposit Polyester Resin Dengan Penguat Serat Daun Nanas Jenis Smoth Cayenne", Univ. Malahayati, Bandar Lampung

[8]. H.P.G. Santafé Júnior, 2010, Mechanical Properties of TensileTested Coir Fiber ReinforcedPolyester Composites. Revista Materia

[9]. Lokantara I Putu, 2010. Pengaruh Panjang Serat pada Temperatur Uji yang BerbedaTerhadap Kekuatan Tarik Komposit Polyester Serat Tapis
Kelapa.Jurnal Ilmiah Teknik Mesin Vol. 4 No.2. Oktober 2010 (166-172)

[10]. Ratni Kartini, 2002. Pembuatan Dan Karakteristik Komposit Polimer Berpenguat Serat Alam. Jurnal Sains Materi Indonesia V01.3 No. 3. Juni 2002 (1411-1098)

[11]. Tumpal Ojahan R.,Perbedaan Kekuatan Tarik ArahTegak Lurus Dan Sejajar SeratUntuk KompositSerat Batang Pisang Bermatriks Recycled Polypropylene (RPP). Fakultas Teknik Universitas Malahayati Bandar Lampung, 2013. 